\title{
USING RBI GRADE 81 A COMPARATIVE STUDY OF BLACK COTTON SOIL AND LATERITIC SOIL
}

\author{
Mamta $^{1}$, Mallikarjun.Honna ${ }^{2}$ \\ ${ }^{\text {I} P o s t ~ G r a d u a t e ~ M . T e c h ~ s t u d e n t, ~ B K I T ~ B h a l k i, ~ K a r n a t a k a, ~ I n d i a . ~}$ \\ ${ }^{2}$ Assistant Professor civil Department, BKIT Bhalki, Karnataka, India.
}

\begin{abstract}
Expansive soils are causing number of damages to the structures particularly light buildings and pavements compare to other natural hazards like earthquake, floods, etc. Thus, worldwide these soils are considered to be problematic soils and pose several challenges for engineers. So, as to utilize these soils in an effective way, proper treatment to the soil is required. With the same intention, an attempt is made to modify engineering properties of black cotton soils by using RBI Grade 81 .
\end{abstract}

Lateritic soil contains more amounts of finer particles like medium sand, fine sand, silt and clay. It could be described as a red friable clay surface in a temperature countries, it could also described as a very hard homogenous vescular massive clinker lateritic soils as a group rather than well defined materials are most commonly found in a leached soils of humid tropic which is enriched in iron and aluminium. In order to fully appreciate the usefulness of lateritic clay soil, its problem (both in field and laboratory but as per project only laboratory experiments will be done) would have to be identified and useful solutions applied, like a soil stabilization, soil stabilization can be divided into two categories namely mechanical and chemical Mechanical stabilization is the blending of different grades of soils to obtain a required grade. Chemical stabilization is the blending of the natural soil with chemical agents. Several blending agents have been used to obtain different effects. The most commonly used agents are Portland cement; asphalt binders and lime, RBI grade 81

Atterberg's limit, California Bearing Ratio (C.B.R.), Unconfined Compressive Strength (U.C.S.) tests has been carried out on the samples of soil and soil with stabilizers. Curing of samples is done for 0,3, days. RBI Grade 81 will be added to the soil in dry state in percentage (by weight) varying from $1 \%$ to $2 \%$ and the tests has been carried out for lateritic (red soil) and black cotton soil.. Black cotton soil and lateritic soil are such that they represent a wide range of variation in their properties

Key words: RBI grade 81, UCS, CBR, BC soil, Lateritic (red) soil.

$* * *$

\section{INTRODUCTION}

In most of the cases the insitu soil will not be having sufficient strength to bear the traffic load coming to it. Many roads fail due to poor sub grade. If the insitu soil is made usable through improvement techniques, this itself will considerably reduce the cost of pavement construction RBI Grade 81 (Road Building International Grade 81) is supplied by Legend Surface Developers, New Delhi. They have the license to manufacture it and has patented it. The product has recently been accredited by Central Road Research Institute, New Delhi. RBI Grade 81 is a combination of naturally occurring compounds. It is widely used in countries like Germany, South Africa, Italy, Spain etc. RBI Grade 81 provides a solution for the creation of low cost roads agricultural roads, parks and forest roads and foundation layers of motorways. It encourages faster application periods. Road can be opened to traffic within 24 hours of final compaction. It provides a dust free surface. If the nature of the soil changes for different depths, most of the methods for stabilization cannot be used. RBI Grade 81 has a wide range of response spectrum.
Response spectrum is the range of soils for which a particular stabilizer can be used. The range over which a soil stabilizer can be used is not the only criteria for its acceptability, as the durability, cost, and ease of application also require consideration. RBI Grade 81 satisfies all these requirements.

Geiman (2005)[1] used a set of traditional and non-traditional stabilizers including quicklime, hydrated lime, pelletized lime, cement, lignosulfonate, synthetic polymer, magnesium chloride, and a Proprietary Cementitious Stabilizer, RBI 81 against three Virginia soils that have caused problems during construction or resulted in poor performance in service.

Shankar et al. (2008) [2] reported that the presence of Pond ash in laterite soil improved the strength properties and resistance to moisture susceptibility and also resulted in the reduction of Maximum Dry Density (MDD) of blend with slight increase in the Optimum Moisture Content (OMC). 
RAASTA (2008) [3] conducted laboratory studies on properties of soils treated with Proprietary Cementitious Stabilizer. In their study they selected four different types of $\mathrm{SC}$ soils and obtained substantial increase in CBR value (to $20 \%$ with $2 \%$ stabilizer). The increase and rate of increase in compressive strength of stabilized soil samples (after 7 days curing) with increasing stabilizer content was not substantial. Hence it was concluded that low percentages about $1-2 \%$ of stabilizer is effective to improve the properties of such clayey soils.

Anitha et al. (2009) [4] reported the optimum stabilizer percentage for red soil, laterite and kaolinite was observed as $4 \%, 2 \%$ and $6 \%$ respectively. The study revealed that both unsoaked and soaked CBR increased significantly with the addition of RBI Grade 81 for kaolinite, red soil and lateritic soil.

Bhuyan (2010) [5] conducted a study using industrial wastes blast furnace slag (BFS) and fly ash. Strength, bearing capacity, volume stability and durability were increased by the method of stabilization using lime and proprietary cementitious stabilizer. The aim of the paper is to study the geotechnical properties of stabilized and unstabilized BC soil.

Biju (2003) [6] studied about the use of TerraZyme for pavement sub grade stabilization. TerraZyme is one of the bioenzyme stabilizers used for stabilizing the soil. This method was found to be most effective for soils containing larger percent of silt. Mithra, et al., (2009) [8] study was undertaken with the objective to find the fast pavement construction technology using in-situ soil by stabilization with a natural soil stabilizer "RBI Grade 81". For the study, a stretch constructed on Reasi Pauni Road, Jammu is taken into consideration. Atterber's Limits, Compaction, CBR, tests were conducted on soil samples with different percentages of RBI 81 with $0 \%$ to 8\%. VENU GOPAL.N; (2009) [9] Studied of soil Properties With Silica fume As Stabilizer And Comparing The same With Rbi-81 And Cost Estimation The laboratory investigations indicate the soil samples have low strength. In order to improve the strength of native soil, the soil samples were treated by varying Silica Fume and RBI- 81 grade content in the range of $1 \%$ to $4 \%$ by weight. The treated soil samples were subjected to triaxial compression test to determine strength of soil.

Aykut Senol et al. [10] based on their experimental work quantified the effect of fly ash stabilization on four different types of soft sub grades encountered using locally available fly ash in Wisconsin. For improvement in engineering properties of soils, a combination of lime and fly ash is beneficial for lower plasticity and higher silt content soils. The fly ash provides the pozzolanic reactants, silica and alumina, lacking in such soils. The maximum dry density of untreated soil was found to be $1.45 \mathrm{~g} / \mathrm{cm} 3$ and OMC was $28.65 \%$. The MDD for mix of soil: RBI Grade 81 for proportion of $98: 2$ and $96: 4$ was found to be $1.45 \mathrm{~g} / \mathrm{cm} 3$ and $1.46 \mathrm{~g} / \mathrm{cm} 3$ respectively. The OMC for mix of soil: RBI Grade 81 for proportion of $98: 2$ and 96:4 were found to be $26.16 \%$ and $25.90 \%$ respectively. the effect of RBI Grade 81 on dry density and OMC of soil. As compared to untreated soil, the modified soil mix of soil: RBI Grade 81 in the proportion of 98:2 led to MDD of $1.45 \mathrm{~g} / \mathrm{cm} 3$ but at reduced OMC. Similarly for mix of soil: RBI Grade 81 for proportion of 96:4, MDD obtained was $1.46 \mathrm{~g} / \mathrm{cm} 3$ and OMC was found to be reduced than untreated soil. It shows that due to addition of RBI Grade 81 the dry density increases and OMC decreases. The important advantage of use of fly ash is that, it solves the problem of disposal of fly ash and protects the environment

\section{AIM OF PRESENT WORK}

1. To evaluate the effect of RBI- 81 on the basic properties of soil.

2. To study the influence of RBI-81 on California Bearing Ratio (CBR) of the soil.

3 . To understand the effect of RBI- 81 on the unconfined compressive strength of the soil

\section{MATERIALS AND METHODOLOGY 3.1 Materials}

The materials used for this study was lateritic soil collected from bidar district where as BC soil collected from college campus of BKIT college bhalki, They were all collected at depth of $2 \mathrm{~m}$ below the natural ground level. These soils were kept safe and dry in jute bags in the Geotechnical laboratory They were air dried for three days to allow partial elimination of natural water which may affect analysis, later sieve analysis has been done and laboratory experiments has been carried out, and the stabilizer RBI 81 has been collected from "Alchemist Technology Ltd from Bangalore.

\subsection{Methodology}

Initially the basic tests performed includes the preliminary tests (grain size analysis, natural moisture contents, specific gravity, and Atterberg's limits) as well as the engineering property tests California Bearing Ratio (CBR), unconfined compression test Tests for unstabilized soil as well as for stabilized soil carried out according to the procedures recommended in the relevant IS codes. For tests of specimens of stabilized soils, specimens prepared by thoroughly mixing the required quantity of soil and stabilizer(RBI $81:-1 \%, 2 \%$ ) in appropriate proportion in dry state and wet state to get a homogeneous and uniform mixture of soil and stabilizer Following tests done on all mixes:-

- Basic test for black cotton soil , red soil and

- For BC soil+ RBI 81, red soil+ RBI 81

- $\quad$ CBR tests to find out CBR value and Unconfined Compressive Strength (UCS) Test for both uncured and 0,3 , days cured specimens, results discussed below 
Table-1: physical properties of RBI 81

\begin{tabular}{|l|l|}
\hline property & explanation \\
\hline appearance & Greyish powder \\
\hline Odour & Odourless \\
\hline Specific gravity & 2.5 \\
\hline Storage & Avoid contact with moisture \\
\hline
\end{tabular}

\section{RESULTS}

Table-2: properties of BC and lateritic soil

\begin{tabular}{|l|l|l|l|}
\hline Sl.no & property & BC soil & Lateritic soil \\
\hline 1 & Specific gravity & 2.4 & \\
\hline 2 & Grain size distribution (\%) & & \\
& Gravel & 3.5 \\
& Sand & 30.5 & 40 \\
& Silt & 44.3 & 25.5 \\
& clay & 24.5 & 34.8 \\
\hline 3 & Consistency limit (\%) & \\
& Liquid limit & 60 & 44.5 \\
& Plastic limit & 45 & 35.3 \\
& Plasticity index & 15 & 9.2. \\
\hline 4 & IS soil classification & MH & CL \\
\hline 5 & Maximum dry density(g/cc) & 1.5 & 1.8 \\
\hline 6 & Optimum moisture content (\%) & 18.5 & 17.8 \\
\hline 7 & California bearing ratio (\%) & 4.5 & 8.3 \\
\hline 8 & Unconfined compressive strength $(\mathrm{kn} / \mathrm{m} 2)$ & 98 & 150 \\
\hline
\end{tabular}

Table -3: Increase value in basic properties of soil with RBI 81 mix

\begin{tabular}{|l|l|l|l|l|l|l|}
\hline & \multicolumn{2}{|c|}{ BC soil } & \multicolumn{3}{l|}{ Lateritic soil } \\
\hline $\begin{array}{l}\text { RBI- } \\
81 \%\end{array}$ & $\begin{array}{l}\text { LL( } \\
\%)\end{array}$ & PL(\%) & PI(\%) & LL(\%) & PL(\%) & PL(\%) \\
\hline 1 & 56.3 & 33.5 & 22.8 & 40.8 & 32.3 & 8.5 \\
\hline 2 & 55.4 & 31.6 & 23.8 & 38.4 & 29.5 & 8.9 \\
\hline
\end{tabular}

Table -4: variation in unconfined compressive strength of soils with RBI-81 mix

\begin{tabular}{|l|l|l|l|}
\hline $\begin{array}{l}\% \text { of } \\
\text { stabilization }\end{array}$ & Days & $\begin{array}{l}\text { UCS qu(KN/m2) } \\
\text { of BC soil }\end{array}$ & $\begin{array}{l}\text { UCS qu(KN/m2) of } \\
\text { Lateritic soil }\end{array}$ \\
\hline $1 \%$ RBI -81 & 0 & 142 & 230 \\
\hline $2 \%$ RBI-81 & 0 & 158 & 280 \\
\hline
\end{tabular}

Table- 5: variation in unconfined compressive strength of soils with RBI-81 mix after curing

\begin{tabular}{|l|l|l|l|}
\hline $\begin{array}{l}\% \quad \text { of } \\
\text { stabilization }\end{array}$ & Days & $\begin{array}{l}\mathrm{UCS} \mathrm{qu}(\mathrm{KN} / \mathrm{m} 2) \\
\text { of BC soil }\end{array}$ & $\begin{array}{l}\mathrm{UCS} \text { qu(KN/m2) of } \\
\text { Lateritic soil }\end{array}$ \\
\hline $1 \%$ RBI -81 & 3 & 178 & 290 \\
\hline $2 \%$ RBI-81 & 3 & 210 & 360 \\
\hline
\end{tabular}


Table- 6: variation in California bearing ratio of soils with RBI-81 mix

\begin{tabular}{|l|l|l|l|l|l|}
\hline \multirow{2}{*}{ Days } & \multicolumn{2}{|l|}{$\begin{array}{l}\text { CBR(\%)with varying } \\
\text { RBI-81 for BC soil }\end{array}$} & & \multicolumn{2}{l|}{$\begin{array}{l}\text { CBR(\%)with varying } \\
\text { RBI-81 for lateritic soil }\end{array}$} \\
\cline { 2 - 6 } & $1 \%$ & $2 \%$ & & $1 \%$ & $2 \%$ \\
\hline 0(unsoaked) & 5.7 & 7.1 & & 11.4 & 12.3 \\
\hline 3days soaked & 7 & 10 & & 13 & 15 \\
\hline
\end{tabular}

\section{CONCLUSIONS}

1. Based on above results Liquid limit and plasticity index decreases with the addition of RBI Grade 81 with varying percentage $(1 \%, 2 \%)$ for both soils which shows good effectiveness of RBI-81

2. From above test unconfined compressive strength of $\mathrm{BC}$ soil and lateritic soil shows strength increases as variation in percentage of RBI-81 increases

3. CBR value for specimens increases more with curing as addition of optimum percentage of RBI-81 increases

Based on the above test results, it can be concluded that RBI81 is effective stabilizer for enhancement of geotechnical properties of lateritic soil and $\mathrm{BC}$ soil

\section{REFERENCES}

[1]. C M Geiman (2005), Stabilization of soft clay sub Grades in Virginia phase I Laboratory study, Master of Science thesis, Virginia Polytechnic Institute and State University, Blacksburg.

[2]. A U R Shankar, S N Suresha and B Kashinath (2008), Characterisation of lateritic soil modified with pond ash and cement, J. of Indian Highways, IRC, pp. 21-27.

[3]. RAASTA Center for Road Technology, Bangalore. Laboratory studies on properties of soils treated with RBI 81 stabilizer, Report submitted to Legend Surface Developers Pvt. Ltd, New Delhi

[4]. K R Anitha, R Ashalatha and A S Johnson (2009), Effects of RBI Grade Different Types of Sub grade Soil, Proc. 10th National Conference on Technological Trends (NCTT09), India.

[5]. S Bhuyan (2010), Stabilization of Blast furnace slag and fly ash using lime and RBI Grade 81, Bachelor of Technology thesis, National Institute of Technology, Rourkela.

[6]. Biju, P. B., (2003), "Studies on Soil Stabilization Using TerraZyme for Pavement Sub grade", M.Tech Thesis, University of Kerala, Trivandrum.

[7]. Mithra Dewars; Satender Kumar \&Mohit Verma; (2009)

"A Case Study On Rapid Pavement Construction by In-Situ Soil Stabilization" Legend Surface Developers Pvt. Ltd., New Delhi

[8]. Venu Gopal.N; (2009), "Study Of Soil Properties With Silica fume As Stabilizer And Comparing The same With Rbi81 And Cost Estimation" Post Graduate Diploma Thesis, Visvesvaraya Technological University, Belgaum.
[9]. Aykut Senola,, Tuncer B.Edilb and Md.Sazzad BinShafiquec, Hector A. Acostad, " Soft subgrades stabilization by using various fly ashes", Resources, Conservation and Recycling 46 ( 2006) 365-37

[10]. Satander Kumar and Anukul Saxena., "Soil and Aggregate Stabilization for Sustainable Pavement" NBM\&CW, December 2010 